\title{
Interactions among environmental drivers: Community responses to changing nutrients and dissolved organic carbon
}

Jennifer L. Klug

Fairfield University, jklug@fairfield.edu

Kathryn L. Cottingham

Follow this and additional works at: https://digitalcommons.fairfield.edu/biology-facultypubs

Copyright 2001 Ecological Society of America

The final publisher PDF has been archived here with permission from the copyright holder.

\section{Peer Reviewed}

\section{Repository Citation}

Klug, Jennifer L. and Cottingham, Kathryn L., "Interactions among environmental drivers: Community responses to changing nutrients and dissolved organic carbon" (2001). Biology Faculty Publications. 41. https://digitalcommons.fairfield.edu/biology-facultypubs/41

\section{Published Citation}

Klug, J. L., \& Cottingham, K. L. (2001). Interactions among environmental drivers: Community responses to changing nutrients and dissolved organic carbon. Ecology, 82(12), 3390-3403.

This item has been accepted for inclusion in DigitalCommons@Fairfield by an authorized administrator of DigitalCommons@Fairfield. It is brought to you by DigitalCommons@Fairfield with permission from the rightsholder(s) and is protected by copyright and/or related rights. You are free to use this item in any way that is permitted by the copyright and related rights legislation that applies to your use. For other uses, you need to obtain permission from the rights-holder(s) directly, unless additional rights are indicated by a Creative Commons license in the record and/or on the work itself. For more information, please contact digitalcommons@fairfield.edu. 


\title{
INTERACTIONS AMONG ENVIRONMENTAL DRIVERS: COMMUNITY RESPONSES TO CHANGING NUTRIENTS AND DISSOLVED ORGANIC CARBON
}

\author{
JenNifer L. KLUG ${ }^{1,3}$ AND KATHRYn L. CotTinghaM ${ }^{2}$ \\ ${ }^{1}$ Department of Zoology, University of Wisconsin, Madison, Wisconsin 53706 USA \\ ${ }^{2}$ Department of Biological Sciences, Dartmouth College, Hanover, New Hampshire 03755 USA
}

\begin{abstract}
Biological communities are frequently exposed to environmental changes that cause measurable responses in properties of the community (hereafter called environmental drivers). Predicting how communities respond to changing environmental drivers is a fundamental goal of ecology. Making predictions, however, can be very difficult, particularly when multiple environmental drivers change simultaneously and there are interactions among the drivers. We investigated the effects of the interaction between changes in nutrient loading and changes in colored dissolved organic matter (measured as dissolved organic carbon, DOC) on the dynamics of phytoplankton communities over a 7-yr period. In 1991, Long Lake, a small seepage lake in northern Michigan, was divided vertically, from sediment surface to water surface, with plastic curtains as part of a whole-lake experiment. The accompanying changes in hydrology led to increases in DOC concentration in one of the basins. Nutrients were added to both basins from 1993 to 1997, causing dramatic changes in phytoplankton community composition. We used multivariate autoregressive models to help interpret the patterns of phytoplankton community composition observed during the experiment. DOC and nutrient addition had diverse effects on phytoplankton: some taxonomic and morphological groups were directly affected by the changes in DOC and nutrients, whereas other groups experienced indirect effects via their interactions with groups that were directly affected. Model results suggest that there was an interaction between the effects of DOC and nutrients for many groups of phytoplankton, such that differences in DOC concentration accounted for differences between basins in response to nutrient addition. The effects of DOC can be explained by changes in physical structure (e.g., thermocline depth and transparency) and water chemistry (e.g., pH) that accompanied changes in DOC concentration. The interaction between DOC and nutrients suggests that predicting community responses to multiple drivers cannot be achieved by simply adding up the effects of single drivers.
\end{abstract}

Key words: aquatic ecology; dissolved organic carbon (DOC); environmental drivers, multiple; Michigan; nutrient loading, lake; phytoplankton; whole-lake manipulation.

\section{INTRODUCTION}

Changes in natural or human-influenced environmental drivers are responsible for many environmental problems (e.g., eutrophication of inland and coastal waters, loss of species due to habitat fragmentation, and global climate change). Environmental drivers are exogenous or endogenous variables that cause measurable changes in properties of a community or ecosystem. Often, communities and ecosystems are exposed to changes in more than one driver simultaneously. Understanding the effects of multiple drivers is important both for enhancing our overall ecological knowledge and for making management and policy decisions (Breitburg et al. 1998).

The response of a system to changes in multiple environmental drivers may be difficult to predict be-

Manuscript received 2 February 2000; revised 2 November 2000; accepted 30 November 2000.

${ }^{3}$ Present address: Biology Department, Fairfield University, Fairfield, Connecticut 06430 USA.

E-mail: jklug@mail.fairfield.edu cause drivers may interact with one another. Many studies have been conducted on interactions between environmental drivers and/or stressors, although these studies tend to extend over a short term and focus on single species (Cairns et al. 1975, Parker 1979, Borgmann 1980, Wallace 1990, Moore and Folt 1993, Pell et al. 1994, Hanazato and Dodson 1995, Folt et al. 1999). Relatively few studies of multiple drivers have been conducted on changes in community composition and dynamics (but see Knight [1987], Turner and Bratton [1987], Chaneton and Facelli [1991], Worthen et al. [1994], Schindler et al. [1996], and Cottingham [1999] for exceptions). Statistically speaking, an interaction between environmental drivers exists if the effects of multiple drivers are greater than or less than the sum (additive model) or product (multiplicative model) of the effects of each driver alone (Sokal and Rohlf 1995). The presence of an interaction is important because it means that it will be more difficult to predict the response to multiple drivers given the response to each driver alone. For example, if we know 
how an ecosystem responds to drivers $\mathrm{A}$ and $\mathrm{B}$ alone, and if we know that the effects of drivers $A$ and $B$ are additive or multiplicative, then we can predict the response of an ecosystem to drivers A and B together. However, if an interaction exists between drivers, then it will be difficult to predict how the ecosystem will respond until we actually apply the two in combination.

Two important environmental drivers in aquatic systems are inorganic nutrients (e.g., nitrogen and phosphorus) and colored dissolved organic matter (hereafter CDOM). Much work has been done on the effects of changes in nutrient inputs (e.g., Schindler 1977, Holmgren 1984, Thompson and Rhee 1994, Carpenter et al. 1996, Cottingham et al. 1998) and CDOM concentrations (e.g., Jones 1992, Arvola et al. 1996, Hessen and Tranvik 1998, Williamson et al. 1999) on lakes. However, less is known about how changes in nutrient input and CDOM concentrations may interact (but see Stewart and Wetzel 1982, Arvola et al. 1996, Carpenter et al. 1998a, Reche et al. 1998).

CDOM is a heterogeneous mixture of organic compounds including humic and fulvic acids (McKnight and Aiken 1998). High levels of CDOM cause lakes to have a tea-like brown color. The heterogeneous nature of CDOM leads to both positive and negative effects on all trophic levels in lakes. For example, the light-absorbing properties of CDOM may reduce primary productivity of algae (Jones 1992, Carpenter et al. 1998b) and protect zooplankton and fish from damaging ultraviolet radiation (Williamson et al. 1994, 1997). Some of the complex effects of CDOM stem from interactions with other drivers in aquatic systems. For example, CDOM may bind metals (e.g., aluminum and copper) and thereby decrease metal toxicity to fish, benthic invertebrates, and phytoplankton (Sunda and Lewis 1978, Driscoll et al. 1980, Burton and Allan 1986, Welsh et al. 1993). In addition, CDOM may alter the availability of phosphorus, iron, and carbon, with dramatic effects on phytoplankton and bacteria (Jackson and Hecky 1980, Stewart and Wetzel 1982, Guilford et al. 1987, Jones et al. 1988, Shaw 1994, Moran and Zepp 1997).

Much of the current work on the effects of CDOM on primary producers focuses on ecosystem-level properties (e.g., primary productivity or total phytoplankton biomass). Fewer studies have looked at how CDOM and its interactions with other environmental drivers (e.g., nutrients) affect phytoplankton community dynamics (but see Chow-Fraser and Duthie 1987, Jones 1998). It is important to look at changes in community composition as well as aggregate measures such as primary productivity because differences in phytoplankton community composition can affect a variety of ecosystem characteristics, such as nutrient cycling (Hessen and Andersen 1992), zooplankton growth rate (Ahlgen et al. 1990), and drinking-water quality (Repavich et al. 1990).

Changes in phytoplankton community composition can be measured in several ways. Algal communities are typically diverse (tens of species per sample), and studies of communities often lump algal species into groups according to taxonomic or morphological characteristics. Groups based on taxonomy may be expected to respond similarly to some environmental drivers (e.g., cyanobacteria are typically negatively affected by low $\mathrm{pH}$ regardless of morphology [Paerl 1988]) whereas morphological groups may be expected to respond similarly to other environmental drivers (e.g., very large phytoplankton are typically resistant to zooplankton grazing regardless of taxonomic affiliation [Leibold 1989]).

In this paper, we focus on the interactions between changes in CDOM concentrations and nutrient input rates, and ask whether the presence of CDOM affects the response of phytoplankton communities to nutrient addition. We analyze data from a whole-lake experiment in which nutrients were added to lakes with different CDOM concentrations (measured as dissolved organic carbon, DOC). We use multivariate autoregressive models to identify which environmental drivers and species interactions might be responsible for the observed changes in the abundances of taxonomic and morphological groups in the phytoplankton community. The autoregressive models allow us to address whether there are interaction effects between DOC and nutrient addition on community composition. Multivariate autoregressive models are useful because they provide a way to quantify interactions in systems with multiple interacting taxa and multiple environmental drivers. This is important because patterns of species interactions may sometimes obscure the effects of environmental drivers. In addition, we explore whether grouping species taxonomically vs. morphologically affects our interpretation of how phytoplankton community composition is affected by nutrients, DOC, and the interaction between the two drivers.

\section{Methods}

\section{Whole-lake experiments}

Our analyses focus on Long Lake, a small seepage lake located in Gogebic County, Michigan (89 $32^{\prime} \mathrm{W}$, $\left.46^{\circ} 13^{\prime} \mathrm{N}\right)$ at the University of Notre Dame Environmental Research Center. During the 1990s, the lake was part of a whole-lake experiment designed to test whether lakes with different food webs responded differently to nutrient addition. Four lakes were included in the experiment, and fish communities were manipulated to produce lakes with differing amounts of zooplanktivory (Carpenter et al. 2001). Because our analyses focus on interactions between DOC and nutrient loading, we used a subset of the original lakes (East and West Long Lakes). We chose these lakes for their strong contrast in DOC concentrations (Christensen et al. 1996) rather than for differences in zooplanktivory. Zooplankton communities in both lakes were domi- 

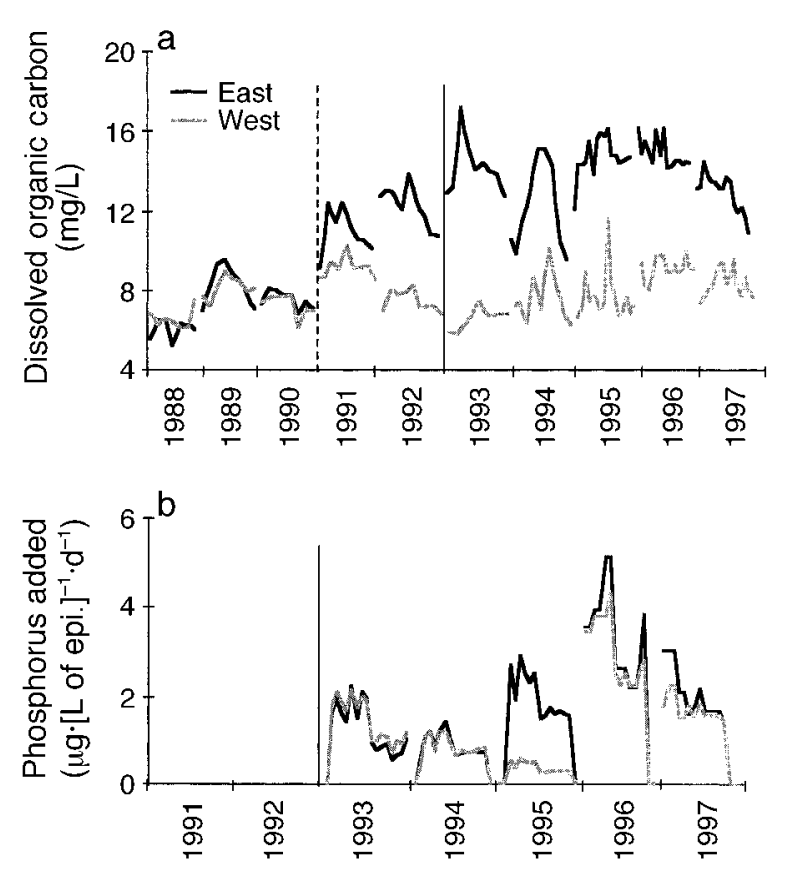

FIG. 1. Time series of (a) dissolved organic carbon concentration (DOC) (data provided by Mike Pace and Jon Cole) and (b) mass of phosphorus added per liter of epilimnion per day in East and West Long Lakes. No nutrients were added in 1991 and 1992. The dashed vertical line in the DOC panel indicates the date the curtain was installed between East and West Long Lakes. The solid vertical line separates the prefertilization years from the fertilized years. Note the difference in time-scale on the $x$-axes of parts (a) and (b).

nated by Daphnia species (Pace et al. 1998, Carpenter et al. 2001). Differences in zooplankton biomass and community composition between East and West Long Lakes were small and variable relative to the contrast provided by the other lakes in the experiment (Carpenter et al. 1996, 2001, Christensen et al. 1996) and do not explain the variability in phytoplankton community composition between lakes (J. L. Klug, unpublished analyses). Here, we describe only the details relevant to this manuscript; the experiment has been thoroughly described elsewhere (Carpenter et al. 1996, 2001, Christensen et al. 1996).

There were two major manipulations of Long Lake. First, in May 1991, Long Lake was divided into three basins (East, West, and Central) using plastic curtains that extended from sediment surface to water surface (Christensen et al. 1996). The east and west basins were used for the analyses described here. The installation of the curtain caused DOC concentrations to increase in East Long Lake (Fig. 1a). DOC concentration increased from pre-curtain values during 1991-1993, remained fairly stable at $\sim 15 \mathrm{mg} / \mathrm{L}$ through 1996 , and began to decrease again in 1997. In contrast, DOC concentration in West Long Lake was variable among years and did not show a consistent trend following curtaining (Fig. 1a). After the curtain was installed, DOC con- centration in West Long Lake was always lower than in East Long Lake. DOC concentration was correlated with thermocline depth (Pearson's correlation coefficient $r=-0.63, n=224$ samples $)$ and the light extinction coefficient $\left(k_{\mathrm{d}}\right)(r=0.85, n=224$ samples). Differences in sediment chemistry may have caused the observed changes in DOC. Groundwater entering East Long Lake flows through organically rich sediments in the littoral zone, whereas the littoral zone sediments in West Long Lake contain more sand (Christensen et al. 1996).

The second manipulation began in 1993, when nitrogen and phosphorus were added to both East and West Long Lakes at a molar N:P ratio of $>30: 1$ (Fig. 1b). Nutrient inputs were highest during the first part of the year to mimic spring runoff. Loading rates were variable among years but were similar between basins within a given year with the exception of 1995 (Fig. $1 \mathrm{~b})$. Background phosphorus loading rates were $0.3-$ $0.4 \mathrm{mg} \cdot \mathrm{m}^{-2} \cdot \mathrm{d}^{-1}$ (Houser et al. 2000).

\section{Limnological analyses}

Lakes were sampled weekly from a central station during summer stratification (late May to mid-September) from 1991 through 1997. Basic limnological sampling included temperature, oxygen, and light profiles, and Secchi depth. Epilimnetic concentrations of dissolved inorganic phosphorus, nitrate, ammonium, total nitrogen, and total phosphorus were quantified using a Lachat autoanalyzer (Lachat Instruments, Milwaukee, Wisconsin, USA). Epilimnetic DOC concentration was measured using either an Astro 2001 TOC analyzer (OI Analytical, College Station, Texas, USA) with persulfate and UV oxidation (1991-1993) or a Shimadzu model 5050 high-temperature TOC analyzer (Shimadzu Scientific Instruments, Columbia, Maryland, USA; 1994-1997). Water $\mathrm{pH}$ was measured on a surface sample. Water samples were pumped into glass bottles such that no air bubbles were trapped. A two-point calibration with buffers bracketing the sample $\mathrm{pH}$ was used to calibrate the $\mathrm{pH}$ meter before measuring sample $\mathrm{pH}$. In addition, the $\mathrm{pH}$ electrode was presoaked extensively in sample water to obtain stable readings.

Phytoplankton were collected by pooling samples from three depths within the epilimnion. Samples were preserved in glutaraldehyde and mounted in methacrylic resin (St. Amand 1990). Phytoplankton were measured and enumerated to species. For each sample, the mean greatest axial linear dimension (GALD), mean individual biovolume (protoplasm exclusive of loricae and sheaths), and concentration were determined for each species (St. Amand 1990, Cottingham 1996).

\section{Construction of phytoplankton groups}

We used two methods to group phytoplankton species. One method was based on taxonomy, and the other method was based on characteristics of individual species. We refer to groups which were lumped according 
to botanical division as "taxonomic groups." These include chlorophytes, chrysophytes, cryptophytes, cyanobacteria, dinoflagellates, and others. Others includes rare taxa (e.g., euglenoids and diatoms) and species of questionable taxonomic affinity.

We refer to groups that were lumped according to characteristics of individual species as "morphological groups." We used two characteristics, size and motility, to construct four morphological groups: small, nonmotile (SNM); large, nonmotile (LNM); small, motile (SM); and large, motile (LM) phytoplankton. We chose size and motility because we expected these traits to influence how particular species respond to changes in nutrients and DOC. Size affects growth rates and uptake kinetics of nutrients (Malone 1980), whereas motility may be important if DOC alters light availability (Jones 1992). We used a cutoff of $30 \mu \mathrm{m}$ to separate small and large phytoplankton (Sprules and Knoechel 1984, Lehman 1988). Previous analyses of data from 1991-1994 yielded consistent results when size cutoffs $\leq 30 \mu \mathrm{m}$ were used whereas cutoffs $>30 \mu \mathrm{m}$ led to ambiguous results (Cottingham 1996). Some species exhibit variability in size and may span across the 30$\mu \mathrm{m}$ cutoff value. We used mean GALD in a particular sample as our size criterion; therefore, an individual species could be in different size classes in different weeks. Motility was based on whether a species possessed flagella or other structures capable of moving them throughout the water column. Taxa that can regulate their buoyancy using gas vesicles (e.g., some cyanobacteria) were also considered motile.

There are a number of physiological traits that may also affect how particular phytoplankton taxa respond to changes in nutrients and DOC. For example, some phytoplankton are able to use organic nitrogen and phosphorus in addition to the inorganic nutrients available to them (Sandgren 1988), which may be a useful trait if DOC contains organic nutrients. In addition, some phytoplankton are capable of phagotrophic ingestion of bacteria (Sanders and Porter 1988). This trait may be beneficial if increases in DOC lead to higher bacterial abundance. We chose not to define groups based on these physiological traits because the existence of these traits is not known for many species. In addition, some phytoplankton may be autotrophic some of the time and phagotrophic at other times, and it would be difficult to have consistent grouping criteria for these species.

\section{Autoregressive models}

We used first-order multivariate autoregressive models (Judge et al. 1985, Ives 1995, Ives et al. 1999, Klug et al. 2000) to describe the possible interactions responsible for changes in phytoplankton community composition observed in East and West Long Lakes. This type of model allows us to quantify the direct effects of environmental drivers (such as nutrients and DOC) as well as the interactions (presumably com- petition) among groups of phytoplankton. Quantifying the interactions among groups of species is necessary in order to infer indirect effects of changing DOC and nutrients on the abundances of the groups of species (Ives 1995). We fit two separate models: one for the five dominant taxonomic groups and one for the four morphological groups. Data from both lakes were analyzed simultaneously.

The model we used was of the form

$$
\mathbf{X}_{t+1}=\mathbf{A}+\mathbf{B} \mathbf{X}_{t}+\mathbf{C} \mathbf{Y}_{t}+\mathbf{E}_{t}
$$

where $\mathbf{X}_{t}$ is a matrix of biovolume of each algal group at time $t, \mathbf{B}$ is a matrix of interaction coefficients between algal groups (e.g., the effect of chrysophytes on chlorophytes), $\mathbf{Y}_{t}$ is a matrix of environmental covariates (e.g., DOC) at time $t, \mathbf{C}$ is a matrix of the effects of each covariate on algal groups (e.g., the effect of DOC on dinoflagellates), $\mathbf{A}$ is a matrix of constants, and $\mathbf{E}$ is a matrix of residuals. Phytoplankton data were $\log (x+c)$ transformed before analysis where $c$ is a constant. We chose the value of $c$ to normalize the error terms $\mathbf{E}_{t}$. Environmental covariates in the model included the mass of phosphorus added each week by the experimenters $(\mathrm{P})$, dissolved organic carbon (DOC), a term for the interaction between DOC and $\mathrm{P}(\mathrm{DOC} \times$ $\mathrm{P}), \mathrm{pH}$, surface water temperature, surface irradiance, and week number and week number squared to account for seasonal effects not represented by the other covariates. We used only phosphorus to represent nutrient loading because the amounts of phosphorus and nitrogen added were highly correlated $(r=0.96, n=224$ samples).

We fit the autoregressive model using least-squares techniques. The full model (Eq. 1) has a large number of parameters, but not all parameters were needed to describe the data. We identified the parameters in the best-fitting model through an exhaustive search of all possible models. The best-fitting subset model was chosen as that with the lowest Akaike Information Criterion (AIC), a measure of model fit that includes a penalty for the number of parameters (Box et al. 1994).

We used an ANOVA-type interaction term for DOC $\times \mathrm{P}$, which assumes that if effects are additive then no interaction exists. In our case, biovolume was logtransformed, so we are assuming that log-additivity (or multiplicativity) means no interaction (Billick and Case 1994). Because the autoregressive models involve no statistical inference, we are not explicitly testing for log-additivity (just as we cannot explicitly test for effects of $\mathrm{P}$ or DOC). Rather, we are using the DOC $\times$ $\mathrm{P}$ term to determine whether an interaction term improves the fit of the model (by reducing the AIC). Because we are using the DOC $\times \mathrm{P}$ term in this way, it is possible for the best-fitting model to contain the DOC $\times \mathrm{P}$ term without containing both DOC and P.

A caveat is needed when interpreting the results of the autoregressive models. Autoregressive models rely on correlated changes in variables. The best-fitting 
TABLE 1. Values for DOC and P used in the long-term mean analysis of the autoregressive models in a study of phytoplankton response to changes in DOC and nutrient conditions in a Michigan lake.

\begin{tabular}{lll}
\hline \hline Variable & \multicolumn{1}{c}{ Value } & \multicolumn{1}{c}{ When observed } \\
\hline DOC low & $6.6 \mathrm{mg} / \mathrm{L}$ & West Long Lake 1993 \\
DOC high & $14.9 \mathrm{mg} / \mathrm{L}$ & East Long Lake 1993 \\
P low & $0.15 \mu \mathrm{g} \cdot \mathrm{L}^{-1} \cdot \mathrm{d}^{-1}$ & East and West Long Lakes 1991, 1992 \\
P high & $3.05 \mu \mathrm{g} \cdot \mathrm{L}^{-1} \cdot \mathrm{d}^{-1}$ & East Long Lake 1996 \\
\hline
\end{tabular}

Notes: High and low values were chosen as the maximum and minimum annual average observed during the experiment. $\mathrm{P}$ is the mass of phosphorus added weekly.

models give the best post hoc description of changes in phytoplankton biovolume, but as with all models based on correlation, they do not constitute tests of the effects.

To explore whether the presence of a DOC $\times \mathrm{P}$ interaction term was biologically important, we compared the magnitude of the effects of $\mathrm{P}, \mathrm{DOC}$, and the interaction between DOC and $\mathrm{P}$ by analyzing the longterm means of the best-fitting autoregressive models. These long-term means were calculated by setting $\mathbf{X}_{t+1}$ $=\mathbf{X}_{t}=\mathbf{X}^{*}$, where $\mathbf{X}^{*}$ is the long-term mean biovolume of phytoplankton groups, and solving Eq. 1 to give

$$
\mathbf{X}^{*}=(\mathbf{A}+\mathbf{C Y} *) /(\mathbf{I}-\mathbf{B})
$$

(Ives 1995). Here, $\mathbf{Y}^{*}$ represents the matrix of longterm mean values of the environmental covariates, and I represents the identity matrix. The long-term means, $\mathbf{X}^{*}$, depend not only on the direct effects of environ-

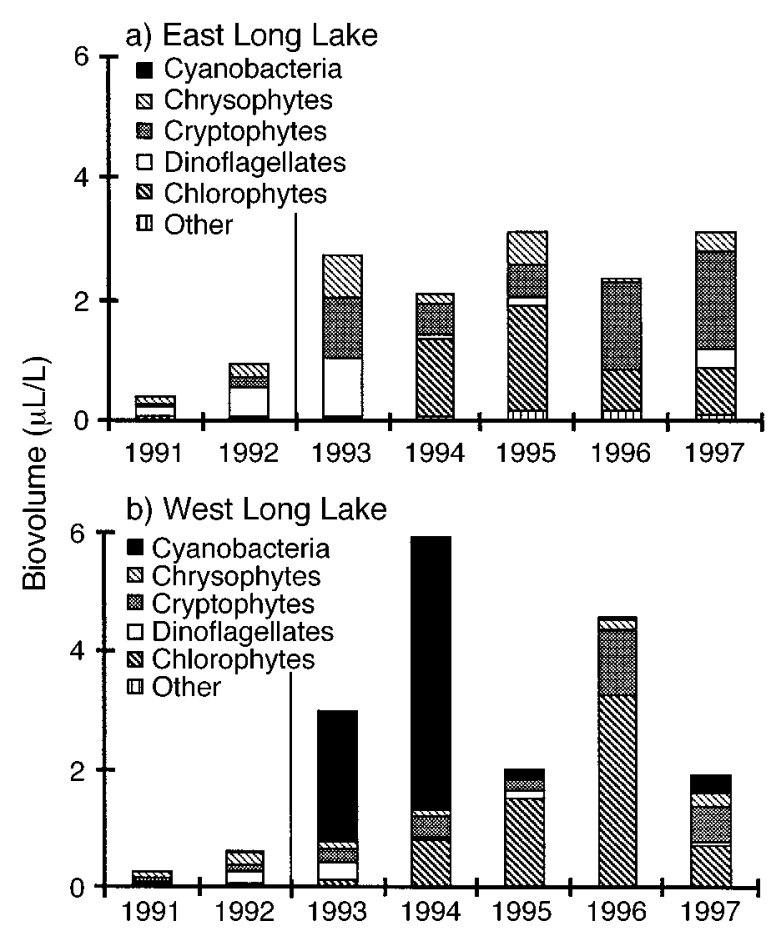

FIG. 2. Yearly averages of biovolumes of taxonomic groups in East and West Long Lakes. "Other"' is the sum of rare groups (diatoms, euglenoids, and miscellaneous). mental drivers, but also on the indirect effects that are caused by changes in the biovolumes of competing groups of phytoplankton. This can be seen in Eq. 2, because $\mathbf{X}^{*}$ depends on $\mathbf{B}$, which gives the interactions among groups of species. Thus, investigating mean biovolumes provides a way of summarizing both direct and indirect effects of environmental drivers on phytoplankton groups. In addition, we can compare the long-term mean biovolume of phytoplankton groups with and without the DOC $\times \mathrm{P}$ interaction.

To determine the impacts of changing DOC and $\mathrm{P}$ on community composition, and to determine the importance of the interaction term DOC $\times$ P, we analyzed five scenarios. First, we calculated baseline biovolume for each group by setting both $\mathrm{P}^{*}$ and $\mathrm{DOC}^{*}$ to the lowest mean annual value observed in either lake basin. Then, we calculated conditions of high-P/low-DOC* and low-P/high-DOC*, where the high values of $\mathrm{P}^{*}$ and $\mathrm{DOC}^{*}$ were taken as the maximum mean annual values observed in either basin. Finally, we considered two cases where both $\mathrm{P}^{*}$ and DOC* were high. In the first case, we set the interaction terms in $\mathbf{Y}^{*}$ to zero to calculate the effects of high $\mathrm{P}^{*}$ and high DOC* if these effects were purely $\log$ additive. In the second case, we used the interaction parameters from the best-fitting autoregressive model. Comparison of the log-additive case vs. the interaction case reveals the biological importance of the interaction between DOC and P. Values for high and low values of $\mathrm{P}^{*}$ and $\mathrm{DOC}^{*}$ are given in Table 1 .

\section{RESULTS}

\section{Phytoplankton community composition: taxonomic groups}

Before nutrients were added (1991-1992), East Long Lake was codominated by dinoflagellates (primarily Peridinium wisconsinense, P. umbonatum, and Gymnodinium sp.) and chrysophytes (Chrysosphaerella sp. and Dinobryon divergens). Cryptophytes were also common members of the community (Fig. 2a). During the pre-enrichment years in West Long Lake, dinoflagellates were less common than in East Long Lake, and chrysophytes (primarily Uroglena sp. and Synura uvella in 1991 and Mallomonas sp. 3 in 1992) and cryptophytes (Cryptomonas sp. 2 and C. ovata) were relatively more common (Fig. 2b). Following nutrient ad- 

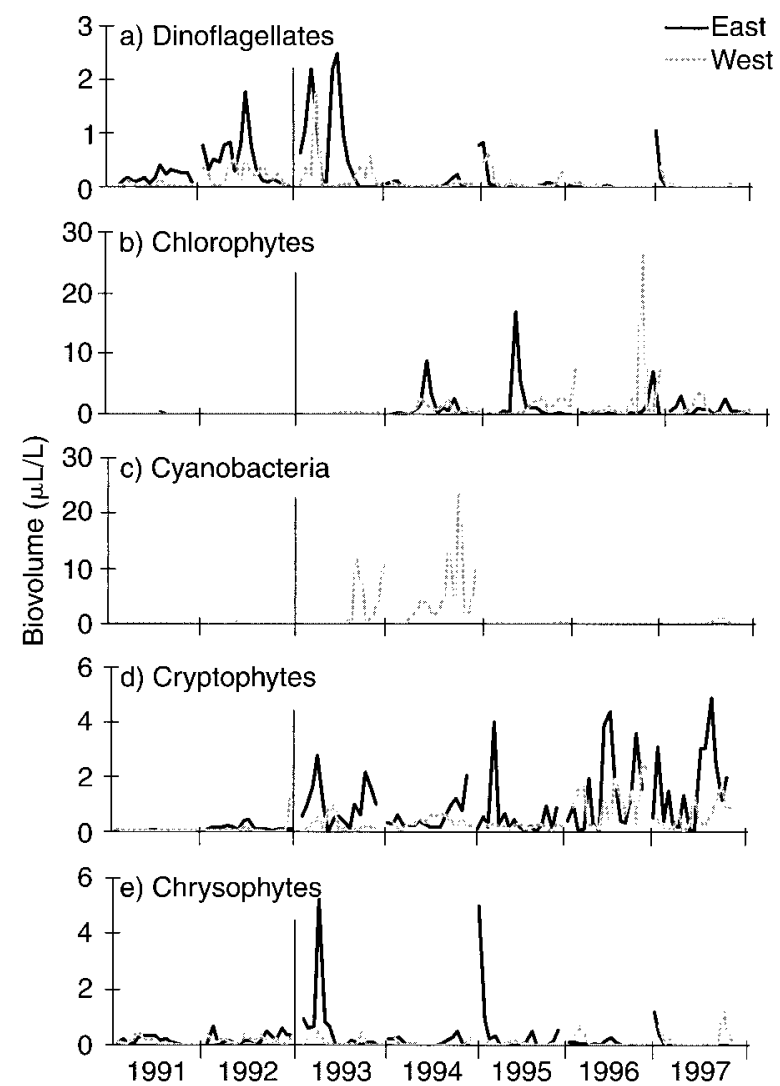

FIG. 3. Time series of biovolumes of (a) dinoflagellates, (b) chlorophytes, (c) cyanobacteria, (d) cryptophytes, and (e) chrysophytes in East and West Long Lakes. The vertical line separates the prefertilization years from the fertilized years.

dition, total phytoplankton biovolume increased and taxonomic composition was drastically altered. Dinoflagellates became rare after the first year of fertilization and chlorophytes became more common (Fig. 3a, b). Cyanobacteria (Anabaena flos-aquae and Anabaena macrospora) formed blooms following fertilization, but only in West Long Lake and only in 1993 and 1994 (Fig. 3c). Cryptophyte biovolume increased in both basins but showed a greater increase in both biovolume and dominance in East Long Lake (Figs. 2 and 3d). Overall, chrysophyte biovolume was fairly stable throughout the experiment, but both basins were more prone to early summer Synura blooms following nutrient addition (Fig. 3e).

\section{Phytoplankton community composition: morphological groups}

During the prefertilization years (1991-1992), East and West Long Lakes were dominated by motile species (Fig. 4a, b). Biovolume of large (LM) and small (SM) motile phytoplankton was similar, and nonmotile species were rare (Fig. 5a-d). During this time, dinoflagellates and chrysophytes dominated the motile groups of algae in both lakes. In addition, Cryptomonas ovata was an important member of motile groups during 1992.

During the first year of fertilization, LM algae increased in both basins of Long Lake. However, the species of LM algae that contributed to the increase were different in the two basins. In East Long Lake, taxa that had been relatively common during 1991 and 1992 (dinoflagellates, cryptophytes, and chrysophytes) increased during the first year of fertilization. In contrast, cyanobacteria (primarily Anabaena flos-aquae and Anabaena macrospora), which had been rare prior to fertilization, were responsible for the increase in LM algae in West Long Lake.

The taxonomic composition of the LM and SM algae shifted further after the first year of fertilization relative to pre-enrichment composition. In both East and West Long Lakes, the composition of motile groups of algae during the last three years of enrichment was dominated more by cryptophytes than by dinoflagellates and chrysophytes.

The biovolume of nonmotile algae (primarily chlorophytes) increased in both basins beginning in 1994 (Fig. 5a, b). In East Long Lake, both large (large colonies of Schizochlamys compacta) and small (Cystomonas starrii and small colonies of Schizochlamys compacta) species contributed to the increase in nonmotile phytoplankton biovolume and remained common for the remainder of the experiment (Fig. 5a, b).

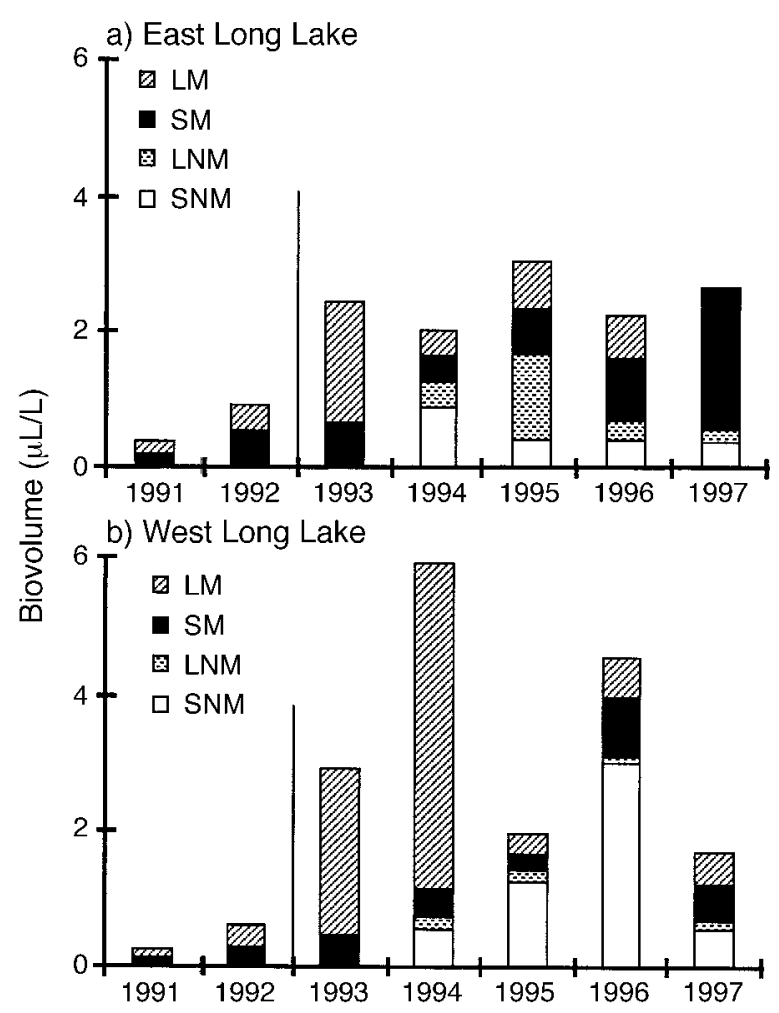

FIG. 4. Yearly average of biovolumes of morphological groups in East and West Long Lakes. 

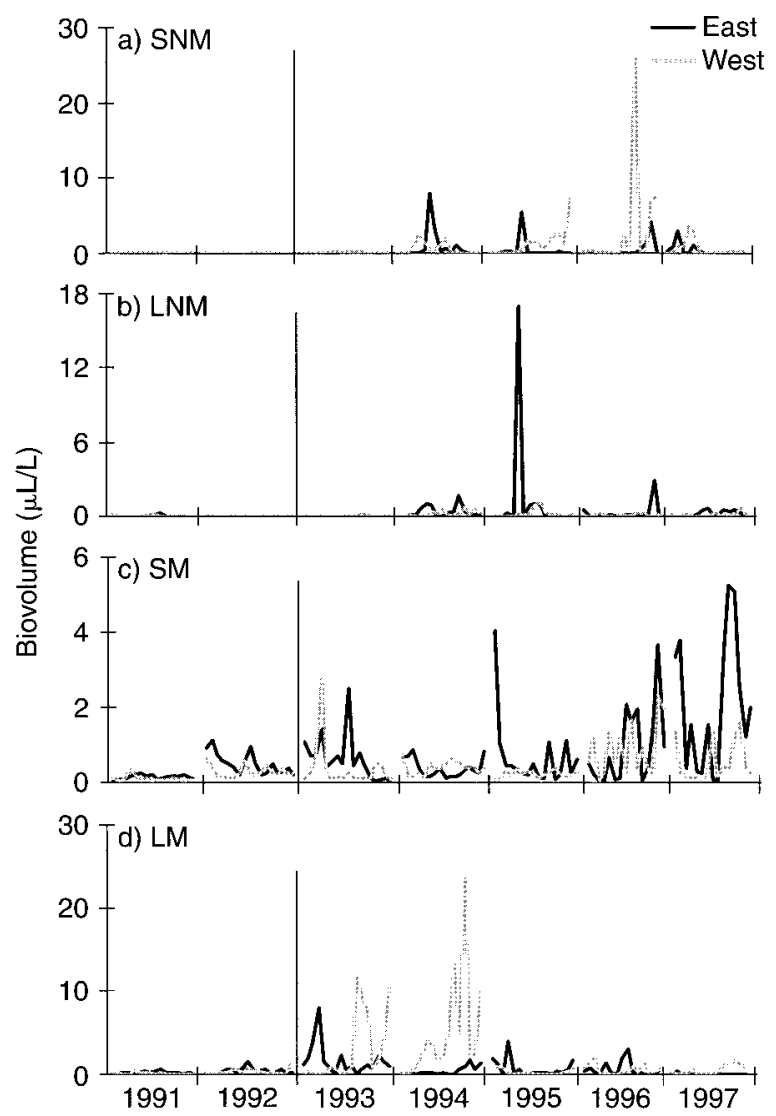

FIG. 5. Time series of biovolumes of (a) SNM (small, nonmotile), (b) LNM (large, nonmotile), (c) SM (small, motile), and (d) LM (large, motile) phytoplankton in East and West Long Lakes. The vertical line separates the prefertilization years from the fertilized years.

In West Long Lake, the increase in nonmotile algae was driven primarily by Cystomonas starrii, a SNM species, and LNM taxa were relatively rare.

\section{Autoregressive models: best-fitting models}

We used the autoregressive models to help interpret the patterns of phytoplankton community composition observed during the experiment. Specifically, we were interested in whether the effects of DOC and P were log additive or whether these drivers interact. Therefore, although most groups were affected by many of the environmental covariates, we will focus on the effects of DOC, P, and the interaction between DOC and P.

The direct effects of each driver were identified using the results of the autoregressive models (Tables 2 and 3, Figs. 6 and 7). Many of the phytoplankton taxonomic and morphological groups were directly affected by DOC concentration and/or the mass of $\mathrm{P}$ added (Tables 2 and 3 ). In addition, model results suggest that for many phytoplankton groups the effects of DOC and $\mathrm{P}$ are not log additive. Including a DOC $\times \mathrm{P}$ interaction term improved the fit of the autoregressive models for four of the five taxonomic groups and two of the four morphological groups (Tables 2 and 3), suggesting that the presence of DOC affects how phytoplankton respond to nutrient loading.

In addition to identifying direct effects of DOC and $\mathrm{P}$ on phytoplankton groups, the autoregressive models also reveal indirect effects: DOC and/or P could affect the abundance of phytoplankton group A by changing the abundance of group B, if group B competes with group A. For example, chrysophytes, the pre-enrichment codominant group, decreased in relative biovolume following nutrient addition (Fig. 2). This appears to be due to an indirect negative effect of increasing P. Model results suggest that chrysophytes are negatively affected by chlorophytes, which in turn are positively affected by nutrient addition (Table 2, Fig. 6). The direct positive effect of nutrients on chlorophytes translates into an indirect negative effect on their competitors, the chrysophytes.

\section{Autoregressive models: analysis of long-term mean biovolume}

We analyzed the long-term means of the autoregressive models to quantify the impact of the interactions between DOC and $\mathrm{P}$ on changes in the abundance of phytoplankton groups. The advantage of this

TABLE 2. Predictors of the change in biovolume of taxonomic groups of algae in an experimentally manipulated lake in Michigan, USA.

\begin{tabular}{|c|c|c|c|c|c|c|c|c|c|c|c|c|c|c|c|}
\hline \multirow{2}{*}{$\begin{array}{l}\text { Group } \\
\text { affect- } \\
\text { ed }\end{array}$} & \multicolumn{13}{|c|}{ Effect of: } & \multirow[b]{2}{*}{$R^{2}$} & \multirow[b]{2}{*}{$R_{-}^{2} D$} \\
\hline & CL & D & $\mathrm{CR}$ & $\mathrm{CH}$ & $\mathrm{CY}$ & $\mathrm{P}$ & DOC & $\mathrm{DOC} \times \mathrm{P}$ & TMP & $\mathrm{pH}$ & SI & Week & $(\text { Week })^{2}$ & & \\
\hline $\begin{array}{l}\text { CL } \\
\text { D }\end{array}$ & -0.42 & $\begin{array}{l}-0.05 \\
-0.43\end{array}$ & -0.60 & & -0.03 & 0.82 & & -0.14 & $\begin{array}{r}0.08 \\
-0.11\end{array}$ & 0.07 & & & & $\begin{array}{l}0.57 \\
0.50\end{array}$ & $\begin{array}{l}0.24 \\
0.25\end{array}$ \\
\hline CR & & -0.09 & -0.58 & & & 0.70 & 0.11 & -0.13 & -0.09 & & -0.02 & -0.58 & 0.01 & 0.52 & 0.31 \\
\hline $\mathrm{CH}$ & -0.23 & & & -0.46 & & & & -0.06 & & & & & & 0.40 & 0.23 \\
\hline $\mathrm{CY}$ & & & & -0.18 & -0.36 & & -0.20 & -0.08 & & 0.67 & 0.05 & & & 0.61 & 0.22 \\
\hline
\end{tabular}

Notes: Shown are results for the best-fitting autoregressive model that predicts these algal-population changes. Each term denotes a term present in the best-fitting model. $\mathrm{CL}=$ Chlorophytes, $\mathrm{D}=$ Dinoflagellates, $\mathrm{CR}=\mathrm{Cryptophytes}, \mathrm{CH}=$ Chrysophytes, and $\mathrm{CY}=$ Cyanobacteria; $\mathrm{P}=$ mass of phosphorus added weekly to the lake, $\mathrm{TMP}=$ epilimnetic temperature, and SI = surface irradiance. $R^{2}$ denotes goodness of fit calculated by comparing predicted to observed biovolume at time $t$ +1 . $R^{2} D$ denotes goodness of fit calculated by comparing predicted to observed change in biovolume from time $t$ to time $t+1$. Data in each column show the effect of a particular phytoplankton group or environmental covariate on the groups in rows. 
TABLE 3. Predictors of the change in biovolume of morphological groups of algae in an experimentally manipulated Michigan lake.

\begin{tabular}{|c|c|c|c|c|c|c|c|c|c|c|c|c|c|}
\hline \multirow{2}{*}{$\begin{array}{l}\text { Group } \\
\text { affect- } \\
\text { ed }\end{array}$} & \multicolumn{11}{|c|}{ Effect of: } & \multirow[b]{2}{*}{$R^{2}$} & \multirow[b]{2}{*}{$R^{2} \_D$} \\
\hline & SNM & LNM & SM & LM & $\mathrm{P}$ & DOC & $\mathrm{DOC} \times \mathrm{P}$ & TMP & $\mathrm{pH}$ & SI & Week $(\text { Week })^{2}$ & & \\
\hline SNM & -0.41 & & & & 1.06 & & -0.18 & 0.06 & 0.86 & & & 0.46 & 0.20 \\
\hline LNM & & -0.72 & & -0.19 & & -0.10 & 0.09 & 0.25 & 0.91 & -0.05 & & 0.30 & 0.43 \\
\hline $\mathrm{SM}$ & & & -0.58 & & 0.13 & & & -0.04 & & & & 0.26 & 0.28 \\
\hline LM & & -0.14 & & -0.54 & & & & & 0.82 & -0.04 & & 0.30 & 0.29 \\
\hline
\end{tabular}

Notes: Shown are results for the best-fitting autoregressive model that predicts change in biovolume of morphological groups of algae. $\mathrm{SNM}=$ small nonmotile, $\mathrm{LNM}=$ large nonmotile, $\mathrm{SM}=$ small motile, and $\mathrm{LM}=$ large motile phytoplankton; $\mathrm{TMP}=$ epilimnetic temperature, $\mathrm{SI}=$ surface irradiance, and $\mathrm{P}=$ mass of phosphorus added weekly to the lake. Each term denotes a term present in the best-fitting model. $R^{2}$ denotes goodness of fit calculated by comparing predicted to observed biovolume at time $t+1 . R^{2} D$ denotes goodness of fit calculated by comparing predicted to observed change in biovolume from time $t$ to time $t+1$. Each column is the effect of a particular phytoplankton group or environmental covariate on the groups in rows.

analysis is that we can model conditions not present in the whole-lake experiment. In the experiment, DOC and $\mathrm{P}$ were changing simultaneously. In this analysis we changed one driver while holding the other driver constant. In addition, analyzing long-term means allowed us to look at the long-term outcome of direct and indirect effects of $\mathrm{P}$ and DOC on phytoplankton dynamics as well as the short-term direct effects. We report results for the analysis of long-term means in terms of percentage difference from the baseline conditions of low P and low DOC (Figs. 8 and 9).

Comparison of the log-additive case and the interaction case shows that interactions between DOC and $\mathrm{P}$ have a strong impact on all phytoplankton groups except SM phytoplankton. Those groups for which a DOC $\times$ P interaction was identified in the best-fitting autoregressive models (Tables 2 and 3) also showed an interaction effect of DOC and P on the long-term biovolume (Figs. 8 and 9). In addition, some groups for

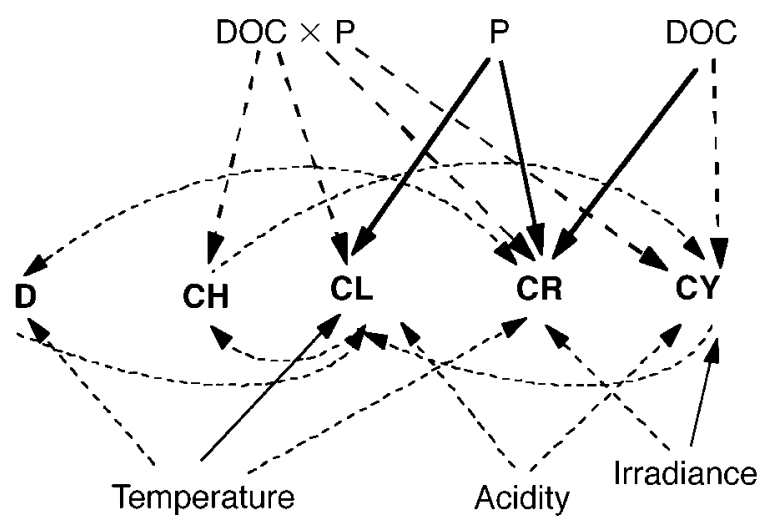

FIG. 6. Results of the best-fitting autoregressive model for biovolumes of taxonomic groups $(\mathrm{D}=$ dinoflagellates, $\mathrm{CH}=$ chrysophytes, $\mathrm{CL}=$ chlorophytes, $\mathrm{CR}=$ cryptophytes, $\mathrm{CY}=$ cyanobacteria) summarized as an interaction web. Arrows represent terms in the model. Solid arrows represent positive effects whereas dashed arrows represent negative effects. Thick arrows represent the focal environmental drivers: DOC, phosphorus, and the interaction between DOC and phosphorus. which no interaction was detected in the direct effects of DOC and $\mathrm{P}$ on short-term changes in biovolume nonetheless showed a DOC $\times \mathrm{P}$ interaction on the longterm mean biovolume. This is because the effects of DOC and $\mathrm{P}$ are filtered through interactions among species. For example, although there are no direct effects of DOC or P on dinoflagellates, this group decreases in response to each driver alone. This is because the group they compete with, the cryptophytes, increases in response to each driver alone. However, there is a negative interaction between DOC and $\mathrm{P}$ for cryptophytes, and in the interaction case, they do not increase as strongly as would be expected compared with the log-additive case. Thus, competitive pressure on dinoflagellates in the interaction case is less than would be expected compared with the log-additive case, and the long-term mean dinoflagellate biovolume in the interaction case is higher than expected based on the logadditive case.

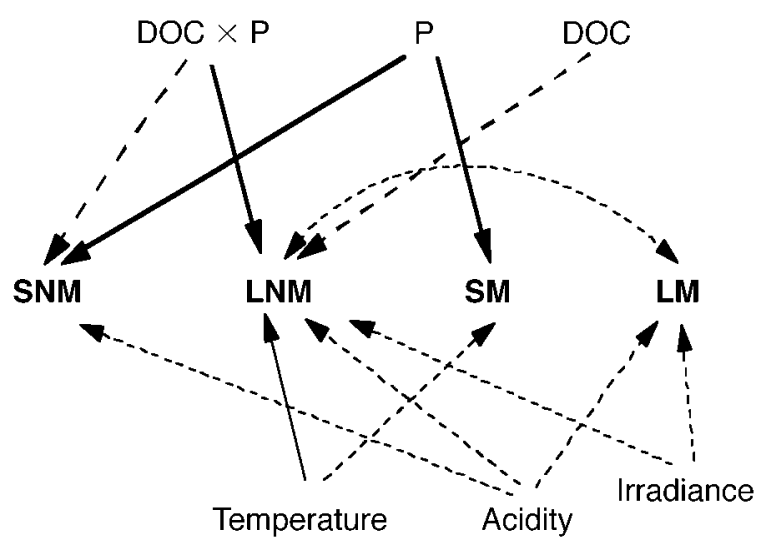

FIG. 7. Results of the best-fitting autoregressive model for biovolumes of morphological groups ( $\mathrm{SNM}=$ small nonmotile, $\mathrm{LNM}=$ large nonmotile, $\mathrm{SM}=$ small motile, and $\mathrm{LM}=$ large motile phytoplankton) summarized as an interaction web. Arrows represent terms in the model. Solid arrows represent positive effects whereas dashed arrows represent negative effects. Thick arrows represent the focal environmental drivers: DOC, phosphorus, and the interaction between DOC and phosphorus. 
a) Chlorophytes

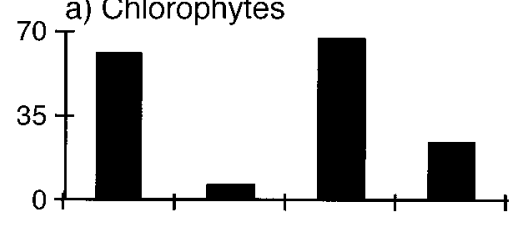

b) Dinoflagellates

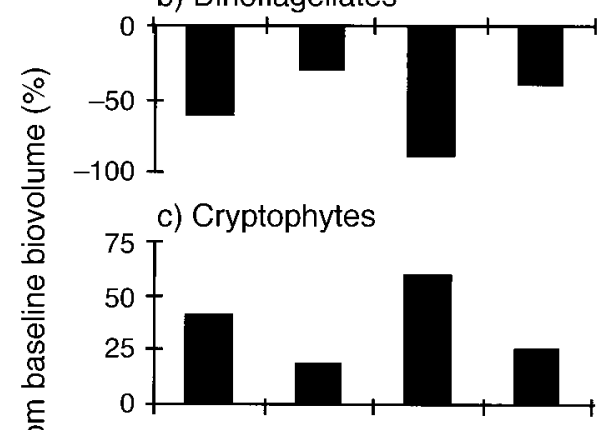

d) Chrysophytes

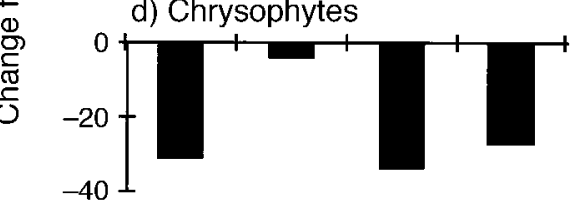

e) Cyanobacteria

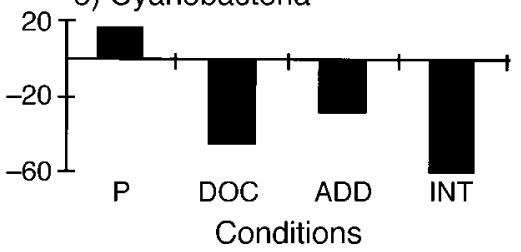

FIG. 8. Results for biovolumes of the (a) chlorophytes, (b) dinoflagellates, (c) cryptophytes, (d) chrysophytes, and (e) cyanobacteria from the long-term mean analysis of the autoregressive models. Each column represents the effects of a different combination of $\mathrm{P}$ and DOC plotted as percentage difference from the baseline algal biovolume. $\mathrm{P}$ denotes high P, low DOC; DOC denotes low P, high DOC; ADD denotes high $\mathrm{P}$, high DOC under the assumption of log-additivity; and INT denotes high P, high DOC given the interactions present in the best-fitting models.

\section{DISCUSSION}

\section{Interactions among multiple environmental drivers}

Very few studies have explicitly addressed the interactive effects of multiple environmental drivers on community composition at the whole-system scale. Our results show that the presence of CDOM (measured as DOC) affects how phytoplankton communities respond to nutrient enrichment. The observed effects of changes in DOC and nutrients on long-term mean biovolume of phytoplankton groups were much different than would be expected if the two drivers did not interact (Figs. 8 and 9). The presence of an interaction between DOC and nutrients suggests that the effects of DOC and nutrients cannot be predicted by simply combining information about the effects of each driver alone. An added complication is that interactions between drivers may be magnified or damped by interactions among groups of species. Therefore, interactions between the direct effects of two environmental drivers on one group of phytoplankton affect the entire phytoplankton community.

We assumed there was an interaction between DOC and $\mathrm{P}$ if their direct effects were not log-additive (multiplicative) effects. The choice of an additive or multiplicative model depends on statistical philosophy and the mechanism by which drivers operate on the response variable (Wootton 1994, Hay 1996, Pennings 1996, Folt et al. 1999). We chose a log-additive (multiplicative) model because multiplicative models are generally more appropriate for experimental data such as abundance or biomass (Wootton 1994) and when

a) SNM
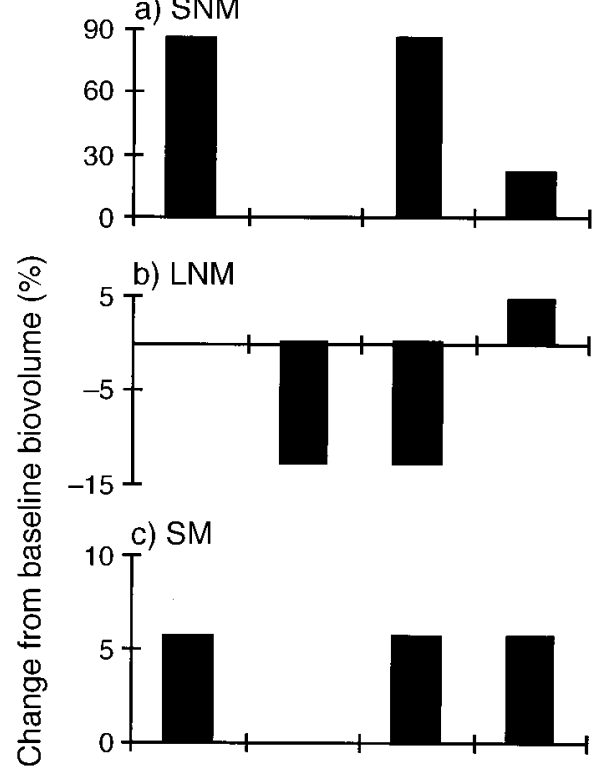

d) LM

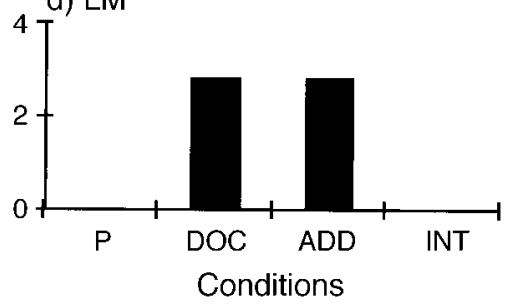

FIG. 9. Results for biovolumes of the (a) SNM (small, nonmotile), (b) LNM (large, nonmotile), (c) SM (small, motile), and (d) LM (large, motile) phytoplankton from the analysis of the long-term means of the autoregressive models. Each column represents a different combination of $\mathrm{P}$ and DOC plotted as percentage difference from the baseline biovolume. $\mathrm{P}$ denotes high P, low DOC; DOC denotes low P, high DOC; ADD denotes high $\mathrm{P}$, high DOC under the assumption of logadditivity; and INT denotes high P, high DOC given the interactions present in the best-fitting models. The absence of a bar means that the particular combination of P and DOC produced no change in long-term biovolume. 
multiple drivers might act on the same physiological process (Folt et al. 1999).

\section{Direct and indirect effects of DOC and nutrients}

Phytoplankton community composition was both directly and indirectly affected by changes in DOC, nutrients, and the interaction between the two drivers. In some cases, the magnitude of the indirect effects was quite large. For example, dinoflagellates were negatively affected by cryptophytes, which were positively affected by added nutrients. Thus, increased nutrients had a strong negative indirect effect on dinoflagellates via cryptophytes. Indirect effects of drivers can only occur when groups of species interact, and thus quantifying interactions among groups is essential for distinguishing between direct vs. indirect effects of drivers.

Joseph Connell's work on barnacles was perhaps the first concrete example documenting indirect effects of physicochemical drivers on communities (Connell 1961). Connell showed that although desiccation had a negative effect on two competing species of barnacles, the effect on the superior competitor (Balanus) was greater than on the inferior competitor (Chthamalus). Chthamalus could only persist in areas that were too dry for Balanus even though Chthamalus itself experienced up to $62 \%$ mortality due to desiccation. For Chthamalus, the loss of its competitor outweighed the direct negative effects of desiccation, which suggests an indirect positive effect of desiccation on Chthamalus (Connell 1961).

Indirect effects of perturbations are likely common, and a challenge is to find ways to measure the important interactions in complex communities. Multivariate autoregressive models provide a powerful tool to identify the direct effects of environmental drivers and the interactions among species. Studies similar to ours have used multivariate autoregressive models to show direct and indirect effects of $\mathrm{pH}$ perturbations mediated by species interactions within zooplankton and phytoplankton communities (Klug et al. 2000, Fischer et al. 2001). We believe that multivariate autoregressive models will also be useful in analyzing data from other ecological communities subjected to complex effects of multiple environmental drivers.

\section{Mechanisms for DOC effects}

The mechanisms by which DOC can directly affect phytoplankton are varied (Jones 1998, Williamson et al. 1999). In our experiment, DOC was highly correlated with the light extinction coefficient. Some of the taxonomic groups that were directly affected by DOC were also directly affected by the amount of surface irradiance (cryptophytes and cyanobacteria) (Table 2). This result coupled with the strong correlation between DOC and the underwater light environment (extinction coefficient) suggest that DOC may have had a direct effect on these groups via changes in light availability.
The cryptophytes are a group that can utilize light at very low light levels (Klaveness 1988) and may experience a competitive advantage in a high DOC, low light environment. In contrast, bloom-forming cyanobacteria can tolerate higher levels of surface light than eukaryotic phytoplankton, and blooms typically form when surface irradiance is high (Paerl 1988). DOC may also have affected phytoplankton by changing the depth of the thermocline, as there was a strong negative correlation between DOC and thermocline depth. Shallow thermoclines favor phytoplankton with slow sinking rates and/or motility that prevent mixing out of the photic zone (Reynolds 1988). Cryptophytes were positively affected by DOC and are a motile group that are able to maintain vertical position in the water column.

Changes in DOC may also alter the chemical environment. Increases in DOC often increase acidity (Driscoll 1989, Hemond 1994). We found that $\mathrm{pH}$ and DOC were not as highly correlated as expected $(r=-0.40$, $n=224$ samples), although $\mathrm{pH}$ was always lower (higher acidity) in the basin with high DOC (East Long Lake); average summer $\mathrm{pH}$ ranged from 5.09-6.07 in East Long Lake and from 5.55-6.51 in West Long Lake (J. Cole and M. Pace, unpublished data). Both taxa that were negatively affected by DOC were also negatively affected by acidity (cyanobacteria and large, nonmotile phytoplankton), which suggests that changes in acidity could also be a mechanism by which DOC affected phytoplankton in these lakes. In addition, groups that were directly affected by phosphorus and had a negative DOC $\times \mathrm{P}$ interaction were also negatively affected by acidity (chlorophytes and small, nonmotile algae), suggesting that changes in acidity could also account for the negative interaction between DOC and nutrients.

There are a number of other mechanisms by which DOC may have affected the phytoplankton community. DOC enters the lake as dissolved organic matter, which contains elements other than carbon (e.g., nitrogen, phosphorus, and iron). These elements may be released to the water column upon entering the lake by photolysis of the organic matter (Francko and Heath 1979, DeHaan 1992, Carlsson and Graneli 1993). Unfortunately, we do not have information about the nature of the DOC entering the lakes described in this manuscript. However, if high DOC in East Long Lake provided phytoplankton with higher levels of nitrogen and phosphorus, we would expect to see differences between basins in the phytoplankton community during the postcurtain, prefertilization years. In contrast, the major difference in phytoplankton community composition occurred following fertilization (Fig. 2), suggesting that DOC did not provide phytoplankton with significant amounts of nitrogen and phosphorus.

Increases in DOC may also affect phytoplankton indirectly by enhancing bacterial production. Many of the taxa in Long Lake are capable of bacterial con- 
sumption and could have benefited from an increase in bacterial production (Jansson et al. 1999). Bacterial production increased in both East and West Long Lake following nutrient addition (Carpenter et al. 2001). Thus, potentially mixotrophic phytoplankton such as the cryptophytes (Klaveness 1988) may have increased following nutrient addition due to increases in bacterial production. However, this mechanism does not explain the differences in phytoplankton dynamics between basins because DOC had no effect on bacterial production (Carpenter et al. 2001). Furthermore, other potential mixotrophs such as the chrysophytes (Sandgren 1988) decreased following nutrient addition, suggesting that mixotrophy was not widespread.

Our results are only partially consistent with previous studies of the effects of nutrients on phytoplankton communities (e.g., Schindler 1977, Thompson and Rhee 1994, Watson et al. 1997, Cottingham et al. 1998), probably due in part to DOC $\times$ nutrient interactions. For example, our results are consistent with previous work in that chlorophytes and cryptophytes were directly stimulated by nutrient addition. Chlorophytes often increase following increases in nutrient loading possibly due to their high demand for phosphorus (Holmgren 1984). Cryptophytes also tend to have a high nutrient demand, and the cryptophytes capable of mixotrophy may have benefited by increased bacterial production following nutrient addition (Klaveness 1988). In other respects, our results are not consistent with previous work. For example, cyanobacteria, which typically increase following increases in nutrient loading (Thompson and Rhee 1994, Watson et al. 1997), only bloomed in one basin and only for a brief period at the beginning of enrichment. Clearly, DOC plays a role in the unexpected results because cyanobacteria were negatively affected by DOC, the interaction between DOC and P, and acidity.

We have assumed that the effects of nutrients were driven by changes in phosphorus. Because nitrogen and phosphorus were added together, we cannot rule out the possibility that some of the nutrient effects were driven by added nitrogen. The amounts of nitrogen and phosphorus added were highly correlated and thus both variables could not be used in the autoregressive models. We chose to represent nutrient loading with phosphorus because it is typically the limiting nutrient in north temperate lakes (Schindler 1977). In addition, prefertilization nutrient limitation experiments at this site showed that phosphorus was the limiting nutrient when the zooplankton community was dominated by large zooplankton (Elser et al. 1988), as was true in East and West Long Lakes. During 1993-1997, dissolved inorganic nitrogen accumulated in the epilimnia of East and West Long Lakes, whereas dissolved inorganic phosphorus only accumulated in 1996 (the year of highest nutrient input) (Carpenter et al. 2001). These results suggest that phosphorus, not nitrogen, was the limiting nutrient for phytoplankton.

\section{Taxonomic vs. morphological groups}

Not surprisingly, results from the two methods of grouping phytoplankton species were similar when there was large overlap between the composition of taxonomic and morphological groups. For example, small, nonmotile phytoplankton were dominated by chlorophytes. Nonetheless, we can make interesting comparisons between the two grouping methods. Patterns that were not detected by taxonomic grouping were striking when taxa were combined morphologically. For example, nonmotile algae were rare during the pre-enrichment years. In addition, there were differences between the autoregressive models in terms of the number of interactions among groups. Negative effects of morphological groups on one another were less common than negative effects of taxonomic groups on one another. Likewise, DOC $\times \mathrm{P}$ interactions were more common for taxonomic groups than for morphological groups.

Our choice of morphological traits for grouping, size and motility, did not always lead to expected patterns. Comparison of the results for taxonomic and morphological groups allows us to explore why this is so. We expected DOC to affect the motile groups positively because of their ability to remain in a favorable light environment. Cryptophytes, which are motile, were positively affected by DOC. However, neither of the morphological groups of motile algae (SM, LM) were affected by DOC. This is likely due to the diverse taxonomic nature of the morphological groups and the multiple mechanisms by which DOC affects phytoplankton. The large, motile group contains many cyanobacteria, which are negatively affected by acidity. Thus, choosing how to group species becomes more difficult when drivers affect species via more than one pathway.

\section{Conclusions}

Interactions among environmental drivers, both biological and statistical, mean that the effects of multiple drivers cannot be predicted by simply combining the effects of single drivers. If our goal is to predict ecological responses to changes in environmental conditions, then we need to be able to anticipate when interactions among drivers are likely to occur.

We have demonstrated that strong interactions between DOC and nutrient loading had large effects on phytoplankton community composition at large spatiotemporal scales. This interaction appears to result from the mechanisms by which nutrients and DOC directly affect phytoplankton: phytoplankton cannot increase in response to increased nutrient loading if they are light limited or if they are physiologically stressed due to high acidity. Similar constraints are likely to hold under other conditions, as well. More research into the mechanisms for both direct and indirect effects of drivers on communities should facilitate the anticipation of 
interactions and improve our ability to predict responses to future environmental change.

\section{ACKNOWLEDGMENTS}

We thank all of the past and current members of the Trophic Cascade project who helped with the whole-lake experiments, laboratory analyses, and data processing. Special thanks to Steve Carpenter, Jon Cole, and Mike Pace who provided unpublished data, and Ann St. Amand who counted the phytoplankton samples. Marty Berg, Ron Hellenthal, and Jeff Runde provided logistic support at UNDERC. Steve Carpenter, Jon Cole, Jeff Houser, Tony Ives, Mike Pace, Val Smith, and three anonymous reviewers provided helpful comments on earlier drafts of this manuscript. The whole-lake experiments and data sets were supported by National Science Foundation (NSF) grants to S. Carpenter, J. Cole, J. Kitchell, D. Lodge, M. Pace, and C. Sandgren. Additional support was provided by a predoctoral fellowship to J. L. Klug (EPA STAR), and an NSF grant to A. R. Ives. Initial programming of the autoregressive models was done in conjunction with the Community Dynamics Working Group supported by the National Center for Ecological Analysis and Synthesis, a Center funded by NSF, the University of California at Santa Barbara, and the State of California.

\section{Literature Cited}

Ahlgen, G. L., M. Brett, and C. Forsberg. 1990. Lipid composition and food quality of some freshwater phytoplankton for cladoceran zooplankton. Journal of Plankton Research 12:809-818.

Arvola, L., P. Kankaala, T. Tulonen, and A. Ojala. 1996. Effects of phosphorus and allochthonous humic matter enrichment on the metabolic processes and community structure of plankton in a boreal lake (Lake Paajaarvi). Canadian Journal of Fisheries and Aquatic Sciences 53:1646-1662.

Billick, I., and T. J. Case. 1994. Higher order interactions in ecological communities: What are they and how can they be detected? Ecology 75:1529-1543.

Borgmann, U. 1980. Interactive effects of metals in mixtures on biomass production kinetics of freshwater copepods. Canadian Journal of Fisheries and Aquatic Sciences 37: 1295-1302.

Box, G. E. P., G. M. Jenkins, and G. C. Reinsel. 1994. Time series analysis. Prentice Hall, Englewood Cliffs, New Jersey, USA.

Breitburg, D. L., J. W. Baxter, C. A. Hatfield, R. W. Howarth, C. G. Jones, G. M. Lovett, and C. Wigand. 1998. Understanding effects of multiple stressors: ideas and challenges. Pages 416-431 in M. L. Pace and P. M. Groffman, editors. Successes, limitations and frontiers in ecosystem science. Springer-Verlag, Berlin, Germany.

Burton, T. M., and J. W. Allan. 1986. Influence of pH, aluminum, and organic matter on stream invertebrates. Canadian Journal of Fisheries and Aquatic Sciences 43:12851289.

Cairns, J., A. G. Heath, and B. C. Parker. 1975. The effects of temperature on the toxicity of chemicals to aquatic organisms. Hydrobiologia 47:135-171.

Carlsson, P., and E. Graneli. 1993. Availability of humic bound nitrogen for coastal phytoplankton. Estuarine Coastal Shelf Science 36:433-447.

Carpenter, S. R., J. J. Cole, T. E. Essington, J. R. Hodgson, J. N. Houser, J. F. Kitchell, and M. L. Pace. 1998a. Evaluating alternative explanations in ecosystem experiments. Ecosystems 1:335-344.

Carpenter, S. R., J. J. Cole, J. R. Hodgson, J. F. Kitchell, M. L. Pace, D. Bade, K. L. Cottingham, T. E. Essington, J. N. Houser, and D. E. Schindler. 2001. Trophic cascades, nutrients, and lake productivity: experimental enrichment of lakes with contrasting food webs. Ecological Monographs 71: $163-186$

Carpenter, S. R., J. J. Cole, J. F. Kitchell, and M. L. Pace. 1998b. Impact of dissolved organic carbon, phosphorus, and grazing on phytoplankton biomass and production in experimental lakes. Limnology and Oceanography 43:7380.

Carpenter, S. R., J. F. Kitchell, K. L. Cottingham, D. E. Schindler, D. L. Christensen, D. M. Post, and N. Voichick. 1996. Chlorophyll variability, nutrient input, and grazing: evidence from whole-lake experiments. Ecology 77:725-735.

Chaneton, E. J., and J. M. Facelli. 1991. Disturbance effects on plant community diversity: spatial scales and dominance hierarchies. Vegetatio 93:143-155.

Chow-Fraser, P., and H. Duthie. 1987. Response of the phytoplankton community to weekly additions of monoammonium phosphate in a dystrophic lake. Archiv für $\mathrm{Hy}$ drobiologie 110:67-82.

Christensen, D. L., S. R. Carpenter, K. L. Cottingham, S. E. Knight, J. P. LeBouton, D. E. Schindler, N. Voichick, J. J. Cole, and M. L. Pace. 1996. Pelagic responses to changes in dissolved organic carbon following division of a seepage lake. Limnology and Oceanography 41:553-559.

Connell, J. H. 1961. The influence of interspecific competition and other factors on the distribution of the barnacle Chthamalus stellatus. Ecology 42:710-723.

Cottingham, J. L., S. R. Carpenter, and A. L. St. Amand. 1998. Responses of epilimnetic phytoplankton to experimental enrichment in three small seepage lakes. Journal of Plankton Research 20:1889-1914.

Cottingham, K. L. 1996. Phytoplankton responses to wholelake manipulations of nutrients and food webs. Dissertation. University of Wisconsin, Madison, Wisconsin, USA.

Cottingham, K. L. 1999. Nutrients and zooplankton as multiple stressors of phytoplankton communities: evidence from size-structure. Limnology and Oceanography 44:810827.

DeHaan, H. 1992. Impacts of environmental changes on the biogeochemistry of aquatic humic substances. Hydrobiologia 229:59-71.

Driscoll, C. T., J. P. Baker, J. J. Bidogni, and C. L. Schofield. 1980. Effects of aluminum speciation on fish in dilute acidified waters. Nature 284:161-164.

Driscoll, C. T., R. D. Fuller, and W. D. Schecher. 1989. The role of organic acids in the acidification of surface waters in the eastern U.S. Water, Air, and Soil Pollution 43:2140.

Elser, J. J., M. M. Elser, N. A. MacKay, and S. R. Carpenter. 1988. Zooplankton-mediated transitions between $\mathrm{N}$ and $\mathrm{P}$ limited algal growth. Limnology and Oceanography 33:114.

Fischer, J. M., T. M. Frost, and A. R. Ives. 2001. Compensatory dynamics in zooplankton community responses to acidification: measurement and mechanisms. Ecological Applications 11:1060-1072.

Folt, C. L., C. Y. Chen, M. V. Moore, and J. Burnaford. 1999. Synergism and antagonism among multiple stressors. Limnology and Oceanography 44:864-877.

Francko, D. A., and R. T. Heath. 1979. Functionally distinct classes of complex phosphorus compounds in lake water. Limnology and Oceanography 24:463-473.

Guildford, S. J., F. P. Healey, and R. E. Hecky. 1987. Depression of primary production by humic matter and suspended sediment in limnocorral experiments at Southern Indian Lake, northern Manitoba. Canadian Journal of Fisheries and Aquatic Sciences 44:1408-1417.

Hanazato, T., and S. I. Dodson. 1995. Synergistic effects of low oxygen concentration, predator kairomone, and a pesticide on the cladoceran Daphnia pulex. Limnology and Oceanography 40:700-709. 
Hay, M. E. 1996. Defensive synergisms? reply to Pennings. Ecology 77:1950-1953.

Hemond, H. F. 1994. Role of organic acids in acidification of fresh waters. Pages 103-115 in C. E. W. Steinberg and R. F. Wright, editors. Acidification of freshwater ecosystems: implications for the future. John Wiley and Sons, New York, New York, USA

Hessen, D. O., and R. Andersen. 1992. The algae-grazer interface: feedback mechanisms linked to elemental ratios and nutrient cycling. Ergebnisse der Limnologie 353:111120.

Hessen, D. O., and L. J. Tranvik, editors. 1998. Aquatic humic substances: ecology and biogeochemistry. SpringerVerlag, Berlin, Germany.

Holmgren, S. K. 1984. Experimental lake fertilization in the Kuokkel area, northern Sweden: phytoplankton biomass and algal composition in natural and fertilized subarctic lakes. International Revue der Gesamten Hydrobiologie 69: $781-817$.

Houser, J. N., S. R. Carpenter, and J. J. Cole. 2000. Food web structure and nutrient enrichment: effects on sediment phosphorus retention in whole-lake experiments. Canadian Journal of Fisheries and Aquatic Sciences 57:1524-1533.

Ives, A. R. 1995. Predicting the response of populations to environmental change. Ecology 76:926-941.

Ives, A. R., S. R. Carpenter, and B. Dennis. 1999. Community interaction webs and zooplankton responses to planktivory manipulations. Ecology 80:1405-1421.

Jackson, T. A., and R. E. Hecky. 1980. Depression of primary productivity by humic matter in lake and reservoir waters of the boreal forest zone. Canadian Journal of Fisheries and Aquatic Sciences 37:2300-2317.

Jansson, M., A. Bergstrom, P. Blomqvist, A. Isaksson, and A. Jonsson. 1999. Impact of allochthonous organic carbon on microbial food web carbon dynamics and structure in Lake Ortrasket. Archiv für Hydrobiologie 144:409-428.

Jones, R. I. 1992. The influence of humic substances on lacustrine planktonic food chains. Hydrobiologia 229:7391.

Jones, R. I. 1998. Phytoplankton, primary production and nutrient cycling. Pages 145-176 in D. O. Hessen and L. J. Tranvik, editors. Aquatic humic substances: ecology and biogeochemistry. Springer-Verlag, Berlin, Germany.

Jones, R. I., K. Salonen, and H. DeHaan. 1988. Phosphorus transformations in the epilimnion of humic lakes: abiotic interactions between dissolved humic materials and phosphate. Freshwater Biology 19:357-369.

Judge, G. G., W. E. Griffiths, R. C. Hill, J. Lutkepohl, and T. C. Lee. 1985. The theory and practice of econometrics. John Wiley and Sons, New York, New York, USA.

Klaveness, D. 1988. Ecology of the Cryptomonadida: a first review. Pages 105-133 in C. D. Sandgren, editor. Growth and reproductive strategies of freshwater phytoplankton. Cambridge University Press, Cambridge, UK.

Klug, J. L., J. M. Fischer, A. R. Ives, and B. Dennis. 2000. Compensatory dynamics in planktonic community responses to acidification. Ecology 81:387-398.

Knight, D. H. 1987. Parasites, lightning, and the vegetation mosaic in wilderness landscapes. Pages 59-83 in M. G. Turner, editor. Landscape heterogeneity and disturbance. Springer-Verlag, New York, New York, USA.

Lehman, J. T. 1988. Selective herbivory and its role in the evolution of phytoplankton growth strategies. Pages 369387 in C. D. Sandgren, editor. Growth and reproductive strategies of freshwater phytoplankton. Cambridge University Press, Cambridge, UK.

Leibold, M. A. 1989. Resource edibility and the effects of predators and productivity on the outcome of trophic interactions. American Naturalist 13:922-949.

Malone, T. C. 1980. Algal size. Pages 433-463 in I. Morris, editor. The physiological ecology of phytoplankton. Blackwell Scientific, Oxford, UK.

McKnight, D. M., and G. R. Aiken. 1998. Sources and ages of aquatic humus. Pages 9-40 in D. O. Hessen and L. J. Tranvik, editors. Aquatic humic substances: ecology and biogeochemistry. Springer-Verlag, Berlin, Germany.

Moore, M. V., and C. L. Folt. 1993. Zooplankton body size and community structure: effects of thermal and toxicant stress. Trends in Ecology and Evolution 8:178-183.

Moran, M. A., and R. G. Zepp. 1997. Role of photoreactions in the formation of biologically labile compounds from dissolved organic matter. Limnology and Oceanography 42: 1307-1316.

Pace, M. L., J. J. Cole, and S. R. Carpenter. 1998. Trophic cascades and compensation: differential responses of microzooplankton in whole-lake experiments. Ecology 79: $138-152$.

Paerl, H. W. 1988. Growth and reproductive strategies of freshwater blue-green algae (cyanobacteria). Pages 261315 in C. D. Sandgren, editor. Growth and reproductive strategies of freshwater phytoplankton. Cambridge University Press, Cambridge, UK.

Parker, J. G. 1979. Toxic effects of heavy metals upon cultures of Uronema marinum (Ciliophora: Uronematidae). Marine Biology 54:17-24.

Pell, E. J., P. J. Temple, A. L. Friend, H. A. Mooney, and W. E. Winner. 1994. Compensation as a plant response to ozone and associated stresses: an analysis of ROPIS experiments. Journal of Environmental Quality 23:429-436.

Pennings, S. C. 1996. Testing for synergisms between chemical and mineral defenses: a comment. Ecology 77:19481950.

Reche, R., M. L. Pace, and J. J. Cole. 1998. Interactions of photobleaching and inorganic nutrients in determining bacterial growth on colored dissolved organic carbon. Microbial Ecology 36:270-280.

Repavich, W. M., W. C. Sonzogni, J. H. Stanridge, R. E. Wedepohl, and L. F. Meisner. 1990. Cyanobacteria (bluegreen algae) in Wisconsin [USA] waters: acute and chronic toxicity. Water Research 24:225-232.

Reynolds, C. S. 1988. Functional morphology and the adaptive strategies of freshwater phytoplankton. Pages 388-433 in C. D. Sandgren, editor. Growth and reproductive strategies of freshwater phytoplankton. Cambridge University Press, Cambridge, UK.

Sanders, R. W., and K. G. Porter. 1988. Phagotrophic phytoflagellates. Advances in Microbial Ecology 10:167-192.

Sandgren, C. D. 1988. Growth and reproductive strategies of freshwater phytoplankton. Cambridge University Press, Cambridge, UK.

Schindler, D. W. 1977. Evolution of phosphorus limitation in lakes. Science 195:260-262.

Schindler, D. W., P. J. Curtis, B. R. Parker, and M. P. Stainton. 1996. Consequences of climate warming and lake acidification for UV-B penetration in North American boreal lakes. Nature 379:705-708.

Shaw, P. J. 1994. The effect of pH, dissolved humic substances, and ionic composition on the transfer of iron and phosphate to particulate size fractions in epilimnetic lake water. Limnology and Oceanography 39:1734-1743.

Sokal, R., and F. J. Rohlf. 1995. Biometry. W. H. Freeman, New York, New York, USA.

Sprules, W. G., and R. Knoechel. 1984. Lake ecosystem dynamics based on functional representations of trophic components. Pages 383-403 in D. G. Meyers and J. R. Strickler, editors. Trophic interactions within aquatic ecosystems. Westview, Boulder, Colorado, USA.

St. Amand, A. L. 1990. Mechanisms controlling metalimnetic communities and the importance of metalimnetic phyto- 
plankton to whole lake primary productivity. Dissertation. University of Notre Dame, South Bend, Indiana, USA.

Stewart, A. J., and R. G. Wetzel. 1982. Influence of dissolved humic materials on carbon assimilation and alkaline phosphatase activity in natural algal-bacterial assemblages. Freshwater Biology 12:369-380.

Sunda, W., and J. A. M. Lewis. 1978. Effect of complexation by natural organic ligands on the toxicity of copper to a unicellular alga, Monochrysis lutheri. Limnology and Oceanography 23:870-876.

Thompson, P., and G. Rhee. 1994. Phytoplankton responses to eutrophication. Ergebnisse der Limnologie 42:155-166.

Turner, M. G., and S. P. Bratton. 1987. Fire, grazing, and the landscape heterogeneity of a Georgia barrier island. Pages 85-101 in M. G. Turner, editor. Landscape heterogeneity and disturbance. Springer-Verlag, New York, New York, USA.

Wallace, A. 1990. Interactions of two parameters in crop production and in general biology: sequential additivity, synergism, antagonism. Journal of Plant Nutrition 13:327342.

Watson, S., E. McCauly, and J. A. Downing. 1997. Patterns in phytoplankton taxonomic composition across temperate lakes of different nutrient status. Limnology and Oceanography 42:487-495.
Welsh, P. G., J. F. Skidmore, D. J. Spry, D. G. Dixon, P. V. Hodson, N. J. Hutchinson, and B. E. Hickie. 1993. Effect of $\mathrm{pH}$ and dissolved organic carbon on the toxicity of copper to larval fathead minnow (Pimephales promelas) in natural lakes waters of low alkalinity. Canadian Journal of Fisheries and Aquatic Sciences 50:1356-1362.

Williamson, C. E., S. L. Metzgar, P. A. Lovera, and R. E. Moeller. 1997. Solar ultraviolet radiation and the spawning habitat of yellow perch, Perca flavescens. Ecological Applications 7:1017-1023.

Williamson, C. E., D. P. Morris, M. L. Pace, and O. G. Olson. 1999. Dissolved organic carbon and nutrients as regulators of lake ecosystems: resurrection of a more integrated paradigm. Limnology and Oceanography 44:795-803.

Williamson, C. E., H. E. Zagarese, P. C. Schulze, B. R. Hargreaves, and J. Seva. 1994. The impact of short-term exposure to UV-B radiation on zooplankton communities in north temperate lakes. Journal of Plankton Research 16: 205-218.

Wootton, J. T. 1994. Putting the pieces together: testing the independence of interactions among organisms. Ecology 75:1544-1551.

Worthen, W. B., S. Mayrose, and R. G. Wilson. 1994. Complex interactions between biotic and abiotic factors: effects on mycophagous fly communities. Oikos 69:277-286. 